\title{
The Influence of eWOM and Customer Satisfaction on Purchasing Decisions
}

\author{
Fahma Rindha Purba1*, Eristia Lidia Paramita ${ }^{2}$
}

1,2 Faculty of Economics and Business, Satya Wacana Christian University, Salatiga, Indonesia

\section{ARTICLE INFO}

\section{Article history:}

Received September 02, 2021

Revised September 03, 2021

Accepted October 18, 2021

Available online November 25, 2021

\section{Keywords:}

eWOM, Customer Satisfaction, Purchasing Decisions

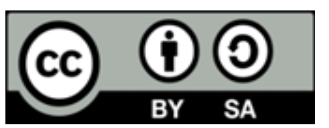

This is an open access article under the CC BY-SA license.

Copyright $(2021$ by Author. Published by Universitas Pendidikan Ganesha.

\begin{abstract}
A B S T R A C T
The current development of technology makes it easier for humans to search for information. Electronic words of mouth (eWOM) or information media through the internet becomes the most widely used media by the public to search for needs, dig information, evaluate alternatives, and make purchasing decisions. After recognizing the needs, the public starts looking for information about the products they need to purchase. The better the review provided by someone, the higher the purchasing interest. This study aims to analyze the effect of eWOM and customer satisfaction on purchasing decisions. This study uses quantitative methods. It involved 132 customers aged 18-60 years old who have purchased Argotelo products as samples. The sample was determined using a purposive sampling technique. The data were analyzed using multiple linear regression. The results of the analysis showed that eWOM affects purchasing decisions. Then, customer satisfaction affects purchasing decisions. Besides, eWOM and customer satisfaction affect purchasing decisions.
\end{abstract}

\section{INTRODUCTION}

The development of information technology has supported innovations to help people do something easier (Burbules et al., 2020; Kintu et al., 2017; Liao et al., 2018). The development of technology increases the number of internet users in which in Indonesia it reaches 17 percent or 25 million with an average usage of 7 hours 59 minutes per day mostly for social media (Fardiah et al., 2020; Supadiyanto, 2020). The number of social media users in Indonesia is 175.4 million people with an average usage of 3 hours 26 minutes per day. Today's society has moved from conventional to digital. Customers choose digital over conventional methods as it is easier to make transactions (Geng et al., 2019; Morrison, 2018; Purnomo et al., 2019). In 2025, the Indonesian economy is projected to transform into the digital era, so that it is necessary to prepare for digitalization. The government provides free training for digital marketers through a website to help business actors to understand and prepare for digitalization. Digitization can be utilized as a means of promotion. Promotion is an effort to inform or offer products or services that aim to attract potential consumers to buy or consume them so that it is expected to increase sales volume (Bigdellou et al., 2022; Lang et al., 2022). Promotional activities will influence consumers to become acquainted with the products offered by the company, which they become happy and then buy the product (Chang \& Su, 2022; Feng et al., 2021; Li et al., 2021). The primary purpose of promotion is to provide information, attract attention, and then influence sales. A promotional activity, if appropriately implemented, can influence consumers about where and how consumers spend their income. Promotion can benefit both producers and consumers (Darmawan et al., 2020; Sinha \& Verma, 2020; Xiaoyan et al., 2019).

The current trend in promotion uses social media. The number of social media users increases from time to time. This condition is seen as an opportunity to market products and to be a communication tool with consumers (Hanaysha, 2017; Hanna et al., 2017; Ong, 2020). One of the effective marketing tools to influence the decision of prospective buyers is word of mouth. However, through the development of technology, it turns into the electronic word of mouth. Before buying a product, consumers will look for the information in various ways (Atiko et al., 2016; Marta \& William, 2016; Mo et al., 2015). Unlike offline purchases, online purchases are not made directly so that they increase the level of risk of uncertainty. Therefore, building trust in customers is vital in online sales. In this case, customers can see the review of the product written on social media or the customer's review of the product covering the advantages and disadvantages and the price of the product (Chawla \& Chodak, 2021; Eslami et al., 2021; Latief \& Ayustira, 
2020). A study revealed that eWOM and customer satisfaction have a significant effect on purchasing decisions (Hidayat, 2015; Oktaviani et al., 2019). It was because informants did not meet in person but write comments on social media and possibly had no honesty in all customers. There are differences in the results of previous studies and the objects regarding the effect of eWOM on purchasing decisions. Thus this study, will re-examine the effect of eWOM on purchasing decisions. This present study modified a previous study with the addition of purchasing decision variable (Oktaviani et al., 2019). This variable was added as this study was intended to identify the influence of eWOM and customer satisfaction on purchasing decisions. Customers see and consider recommendations from other consumers and the information provided before buying a product. eWOM can influence consumer behavior in terms of interest, decisions, and customer satisfaction.

A study found that consumer satisfaction helps companies to find out what consumers want so that they will get satisfaction and make repeat purchases which will provide benefits to producers (Agarwal et al., 2021; Ilhamudin, 2020; Moudi et al., 2021). Then, studies revealed that customer satisfaction can be influenced by social media marketing, corporate social responsibility, and price promotion, and service quality (Blake et al., 2022; Hanaysha, 2017). The higher the quality of service provided to consumers, the higher the customer satisfaction and vice versa (Handoko, 2017). This is important to improve service quality to provide satisfaction at an optimal level. Therefore, this study aims to determine the influence of eWOM and customer satisfaction on purchasing decisions for MSME Argotelo Salatiga which is one of the MSME centers for processed food made from cassava such as singkong goreng keju, gemblong chotot, and singkong coklat.

\section{METHODS}

This study used quantitative methods. The analysis focused on the influence of electronic word of mouth (eWOM) and customer satisfaction variables on purchasing decisions of MSME products. This study used primary data obtained by researchers independently. Primary data were collected by distributing online questionnaire to a number of MSME Argotelo customers. The questionnaire used in a Likert scale. The independent variables were eWOM (X1) and customer satisfaction (X2), while the dependent variable was purchasing decision (Y). The population of this study was people who live in Salatiga and its surroundings. The sample was 132 customers who have consumed Argotelo products and aged 18-60 years selected with a purposive sampling technique. Primary data were collected using a questionnaire distributed to some customers of Argotelo online. The data were then analyzed using multiple linear regression.

\section{RESULTS AND DISCUSSIONS}

\section{Results}

Based on the results of the study, the characteristics of the respondent can be seen in Table 1.

Table 1. Characteristics of Respondents

\begin{tabular}{|c|c|c|c|c|}
\hline \multicolumn{2}{|c|}{ Characteristics of Respondents } & \multirow{2}{*}{$\begin{array}{c}\text { f } \\
37\end{array}$} & \multirow{2}{*}{$\begin{array}{c}\% \\
28,03\end{array}$} & \multirow{2}{*}{$\frac{\text { Number }}{132}$} \\
\hline 1. Age & 18-23 years old & & & \\
\hline & 24-29 years old & 18 & 13,64 & \\
\hline & $30-35$ years old & 19 & 14,39 & \\
\hline & $>35$ years old & 58 & 43,94 & \\
\hline \multirow[t]{2}{*}{ 2. Sex } & Male & 29 & 21,97 & 132 \\
\hline & Female & 103 & 78,03 & \\
\hline \multirow[t]{2}{*}{ 3. Dwelling } & Inside Salatiga City & 95 & 71,97 & 132 \\
\hline & Outside Salatiga City & 37 & 28,03 & \\
\hline \multirow[t]{2}{*}{ 4. Social Media Ownership } & Yes & 132 & 100,00 & 132 \\
\hline & No & 0 & 0,00 & \\
\hline \multirow[t]{2}{*}{ 5. Frequently Used Social media } & Facebook & 41 & 31,06 & 132 \\
\hline & Instagram & 91 & 68,94 & \\
\hline \multirow[t]{2}{*}{ 6. Length of Using Social Media $>2.5$ years } & Yes & 11 & 8,33 & 132 \\
\hline & No & 121 & 91,67 & \\
\hline \multirow[t]{2}{*}{ 7. Looking for MSME through Social Media } & Yes & 132 & 100,00 & 132 \\
\hline & No & 0 & 0,00 & \\
\hline 8. Frequently bought products & Gemblong cothot & 11 & 8,33 & 132 \\
\hline
\end{tabular}




\begin{tabular}{|c|c|c|c|c|}
\hline \multicolumn{2}{|c|}{ Characteristics of Respondents } & \multirow{2}{*}{$\begin{array}{l}\text { f } \\
6\end{array}$} & \multirow{2}{*}{$\begin{array}{c}\% \\
4,55\end{array}$} & \multirow[t]{2}{*}{ Number } \\
\hline & Gethukgoreng keju & & & \\
\hline & Singkong hot mayo & 3 & 2,27 & \\
\hline & Singkong keju & 51 & 38,64 & \\
\hline & Singkong original & 27 & 20,45 & \\
\hline & Singkong rich cheese & 3 & 2,27 & \\
\hline & Singkong siap goring & 27 & 20,45 & \\
\hline & Timus crispy & 4 & 3,03 & \\
\hline \multirow[t]{2}{*}{ 9. Online Review before purchasing products } & Yes & 132 & 100,00 & 132 \\
\hline & No & 0 & 0,00 & \\
\hline \multirow[t]{2}{*}{ 10. Others' Review before purchasing products } & Yes & 119 & 90,15 & 132 \\
\hline & No & 13 & 9,85 & \\
\hline \multirow[t]{3}{*}{ 11. Frequency of Purchasing the Product } & $<=1 \mathrm{X}$ & 35 & 26,52 & 132 \\
\hline & $>=2 \mathrm{X}$ & 53 & 40,15 & \\
\hline & $>=3 \mathrm{X}$ & 44 & 33,33 & \\
\hline
\end{tabular}

Out of 132 respondents, $78.03 \%$ were female, aged < 35 years old, and lived in Salatiga City. A total of $68.94 \%$ of the respondents said that Instagram become the most used social media and the length of its use of $<2.5$ years reached $91.67 \%$. Regarding the purchase of Argotelo MSME products, all respondents stated that they knew Argotelo MSME products through social media. In deciding to purchase products of MSME Argotelo, besides reading online reviews, most of the respondents considered other people's reviews $(90.15 \%)$ to find out about the product. In the frequency of purchase, the respondents stated that they bought the product twice (40.15\%). The mostly purchased product was Singkong Keju (38.64\%), followed by Singkong Original (20.45\%) and Singkong Siap Goreng (20.45\%). Based on the results of the analysis, the $\mathrm{r}$-count is in the range of $0.499-0.921>$ r-table $(0.361)$ meaning that the indicators in each questionnaire are valid. It indicates that the questionnaire is feasible to use. The results of the reliability test showed the Cronbach alpha value for each variable of $0.917-0.940>0.6$, meaning that the questionnaire is reliable. This study used the Kolmogorov-Smirnov test with p-value criteria (asymp. sig) $>0.05$ meaning that the data are normally distributed. The value of Kolmogorov-Smirnov Z is 1.162 with a significance value of 0.134 . Thus, the data are categorized normal as the significance value is $0.134>0.05$. The multicollinearity test showed the tolerance value of each independent variable $>0.10$, while the VIF value of each independent variable is $<10$. It indicates that the regression model built does not contain symptoms of multicollinearity. Thus, it can be said that there is no significant correlation between the independent variables in the built model.

This study used the heteroscedasticity test of the Park test. The results showed that each variable has a significance value $>0.05$ (eWOM $(X 1)=0.189$; Customer Satisfaction $(X 2)=0.353$ ). Thus, the regression model is free from heteroscedasticity symptoms. It means that there are no symptoms of heteroscedasticity or there is a similarity of variance from the residuals of one observation to another. The results of the linearity test showed that the regression is linear. It indicates that each independent variable has a relationship with the dependent variable at Deviation from Linearity $>0.05$. Deviation from Linearity of Purchase Decision (Y) and eWOM (X1) is $0.173>0.05$, and Deviation from Linearity of Purchase Decision $(\mathrm{Y})$ and Customer Satisfaction (X2) is $0.448>0.05$.

The results of multiple regression analysis showed that the value of the Adjusted coefficient ( $R$ Square) is $0.814(81.40 \%)$. It means that the variation of the dependent variable of the purchase decision (Y) can be explained by the independent variable (X) of eWOM (X1) and Customer Satisfaction (X2) with $81.40 \%$. The t-count value of the eWOM variable (X1) is 7.698 and Customer Satisfaction (X2) is 6.359. These two variables influence purchasing decisions as they have a t-count value higher than the t-table of 1.657. It is in accordance with the proposed hypotheses I and II which state that eWOM and Customer Satisfaction variables partially affect purchasing decisions. Based on the coefficients table above, the multiple linear regression equation can also be explained as follows: $\mathrm{Y}=0.907+220 \mathrm{X} 1+0.437 \mathrm{X} 2$. Based on this equation, the regression coefficient value of the eWOM variable $(\beta 1)$ is 0.220 . It means that every one-unit increase in eWOM will increase the purchasing decision by 0.220 units with the assumption that other variables are considered ceteris paribus. The regression coefficient value of the Customer Satisfaction variable $(\beta 2)$ is 0.437 meaning that every one-unit increase in Customer Satisfaction will increase the purchasing decision by 0.437 units with the assumption that other variables are considered ceteris paribus. The equation also explains that the regression coefficient of the Customer Satisfaction variable $(\beta 2)$ is higher than the regression coefficient of the eWOM variable ( $\beta 1)$. It indicates that Customer Satisfaction has a greater influence on the purchasing decision of Argotelo MSME products (Y) than the eWOM variable. In 
this study, eWOM was assessed using 14 (fourteen) indicators. The summary of the results of the eWOM questionnaire can be seen in Table 2 .

Table 2.Respondents' Responses to eWOM

\begin{tabular}{|c|c|c|}
\hline No. & $\begin{array}{c}\text { Statement } \\
\text { eWOM (X1) } \\
\end{array}$ & $\begin{array}{c}\text { Mean } \\
\text { Item }\end{array}$ \\
\hline 1 & Through social media, I get information about MSME Argotelo's products & 3,96 \\
\hline 2 & $\begin{array}{l}\text { Through social media, I get other's concerns when providing information about MSME } \\
\text { Argotelo's products }\end{array}$ & 3,95 \\
\hline 3 & $\begin{array}{l}\text { Through social media, I don't have to spend a lot of money looking for information on } \\
\text { MSME Argotelo's products }\end{array}$ & 4,27 \\
\hline 4 & $\begin{array}{l}\text { Through social media, I can save time in finding information on MSME Argotelo's } \\
\text { products }\end{array}$ & 4,36 \\
\hline 5 & Through social media, I see positive comments about MSME Argotelo’s products & 4,14 \\
\hline 6 & Through social media, I get information about MSME Argotelo's product choices & 4,26 \\
\hline 7 & Through social media, I get the location of the MSME Argotelo & 4,38 \\
\hline 8 & $\begin{array}{l}\text { Through social media, I got information about the advantages of MSME Argotelo's } \\
\text { products }\end{array}$ & 4,16 \\
\hline 9 & $\begin{array}{l}\text { Through social media, I can see the willingness of other people to share photos or } \\
\text { videos of MSME Argotelo's products }\end{array}$ & 4,13 \\
\hline 10 & Through social media, I can feel satisfied with MSME Argotelo's products & 4,08 \\
\hline 11 & Through social media, I can feel that MSME Argotelo's products are the right choice & 4,08 \\
\hline 12 & $\begin{array}{l}\text { Through social media, I can see other people's positive experiences with MSME } \\
\text { products }\end{array}$ & 4,18 \\
\hline 13 & I'm looking for advice about MSME Argotelo's products on social media & 3,95 \\
\hline 14 & I ask about the advantages of MSME Argotelo's products on social media & 3,92 \\
\hline \multicolumn{2}{|r|}{$\begin{array}{ll}\text { Mean Total } \\
\end{array}$} & 4,13 \\
\hline
\end{tabular}

The 14 indicators assessed, indicator number 7 (seven), 'Through social media, I get the location of MSME Argotelo' has the highest mean value of 4.38 and indicator number 14 has the lowest mean value of 3.92. Meanwhile, overall respondents consider eWOM in the high category with a total mean of 4.13. It means that respondents are active in seeking information or recommendations about MSME Argotelo by utilizing social media. Customer satisfaction was assessed using six indicators. The summary of respondents' responses to customer satisfaction at MSME Argotelo can be in Table 3.

Table 3. Respondents' Response to Customer Satisfaction

\begin{tabular}{clc}
\hline No & \multicolumn{1}{c}{$\begin{array}{c}\text { Customer Satisfaction (X2) } \\
\text { I am satisfied with the services provided by MSME Argotelo }\end{array}$} & $\begin{array}{c}\text { Mean } \\
\text { Item }\end{array}$ \\
\hline 1 & $\begin{array}{l}\text { I } \text { I feel that the price offered is in accordance with the quality offered by MSME } \\
2\end{array}$ & 4,08 \\
& Argotelo & 4,18 \\
3 & I am satisfied with the speed of service of MSME Argotelo & 4,09 \\
4 & I will repurchase MSME Argotelo's products & 4,17 \\
5 & I am willing to recommend MSME Argotelo's products to families \\
6 & I am willing to recommend MSME Argotelo's products to close friends & 4,21 \\
\hline & Mean Total & $\mathbf{4 , 1 4}$ \\
\hline
\end{tabular}

The assessed indicator in which indicator number 6 has the highest mean value of 4.21 , while indicator number 1 has the lowest mean value of 4.08. Meanwhile, overall, respondents rated customer satisfaction in the high category with a total mean of 4.14. It indicates that respondents are satisfied with MSME Argotelo. In this study, the purchasing decisions were assessed using six indicators, in Table 4.

Table 4. Respondents' Response to Purchasing Decision

\begin{tabular}{ccc}
\hline No. & $\begin{array}{c}\text { Statement } \\
\text { Purchasing Decision (Y) }\end{array}$ & Mean \\
\hline 1 & I want to buy MSME Argotelo's products after seeing the product on social media. & 4,08 \\
2 & I bought MSME Argotelo's products because they have good quality. & 4,18 \\
\hline
\end{tabular}




\begin{tabular}{clc}
\hline No. & \multicolumn{1}{c}{$\begin{array}{c}\text { Statement } \\
\text { Purchasing Decision (Y) }\end{array}$} & Mean \\
\hline 3 & $\begin{array}{l}\text { I bought MSME Argotelo's products based on the other's recommendations on social } \\
\text { media }\end{array}$ & 3,96 \\
4 & $\begin{array}{l}\text { I bought MSME Argotelo's products because the information on social media was very } \\
\text { convincing }\end{array}$ & 4,05 \\
5 & I ask a friend about the MSME Argotelo's products & 4,03 \\
6 & I need MSME Argotelo's products for needs or souvenirs & 4,15 \\
\hline \multicolumn{1}{c}{ Mean Total } & $\mathbf{4 , 0 8}$ \\
\hline
\end{tabular}

The assessed indicators in which indicator number 2 has the highest mean value of 4.18, while indicator number 3 has the lowest mean value of 3.96. Overall, the respondents assessed the purchasing decision in the high category with a total mean value of 4.08. It shows the respondent's purchasing decision of MSME Argotelo's product is high. Electronic word of mouth (eWOM) variable affects purchasing decisions with a significance value of $0.00<0.005$. It means that the presence of eWOM greatly attracts the customer to buy the product.

\section{Discussion}

Before buying a product, the customer will look for information including the review of the product on social media or review by others who have purchased the product (Agustinus \& Junaidi, 2020; Ievansyah \& Sadono, 2018; Latief \& Ayustira, 2020). eWOM as a form of positive or negative review and information given by someone who has purchased the product can be easily seen by a wide audience through the internet. eWOM refers to both new and old consumers' reviews on the internet about a product they have purchased (Soliana \& Pratomo, 2016; Tantriana \& Widiartanto, 2019). eWOM can provide a new alternative to openly sharing information. Business actors consider eWOM important for business activities as it can increase brand awareness and company reputation among consumers. A total of $78.03 \%$ of female respondents aged between 18-35 years stated that in deciding to purchase MSME Argotelo's product, they previously read online reviews either on Instagram (68.94\%) or Facebook (31.06\%) with an average score of 4.13. Besides, respondents stated that they get information about products through social media with an average score of 3.96 and they can seek advice on social media about the products with an average score of 3.95. Furthermore, $68.94 \%$ of respondents who use Instagram revealed that when they will buy a product, they can ask about the advantages of the product through social media with an average score of 3.92. The results of this study, one of the effective marketing tools to influence the decisions of prospective buyers is communication through electronic word of mouth. In the end, the positive impact of eWOM assessed influences the respondents' decision to purchase a product with an average score of 4.08 (Latief \& Ayustira, 2020). eWOM has a significant influence on purchasing decisions in which customers who will buy a product will certainly seek information including comments or responses from other customers who have purchased the product. In other words, the customer decides to purchase the product after seeing online reviews on social media (Eslami et al., 2021; Rahardja et al., 2019).

The results showed that customer satisfaction influences purchasing decisions with a significance value of $0.00<0.005$. Customer satisfaction is a person's feeling of pleasure or disappointment, which resulted from comparing a product's perceived performance or outcome against his/her expectation. The customer satisfaction is satisfaction with a product or service and willingness to repurchase and share experiences in using the product (Hanaysha, 2017; Handoko, 2017; Oktaviani et al., 2019; Pardede, 2017). The expected level of performance of a particular product is influenced by the characteristics of the promotional factors and the customer itself. A total of 78.03\% of female respondents aged between 18-35 years stated that they can buy products $>=2 \mathrm{x}$ in a month with an average score of $40.15 \%$. The most frequently bought products are singkong keju (38.64\%), singkong original $(20.45 \%)$ and singkong siap goreng $(20.45 \%)$. The respondent's willingness to consistently purchase these products shows that they are satisfied with the product. It is in line with a study that consumer satisfaction affects purchasing decisions. This study supports a previous study which if customers are satisfied, they will buy back the products or services that have been purchased (Hidayat, 2015; Imron, 2019; Oktaviani et al., 2019). Satisfied consumers will also give good reviews of products or services to others and vice versa.

The results showed that the eWOM and customer satisfaction variables affected purchasing decisions with a significance value of $0.00>0.05$. A total of $78.03 \%$ of female respondents aged 18-35 years stated that most of them bought the product because of the good quality of the product. It supports a previous study in which purchasing decisions cannot be separated from these two factors (Hidayat, 2015). Thus, the higher the eWOM present by the customer, the higher the customer satisfaction and finally resulting in higher decision to purchase. The results of this study also found that eWOM and customer 
satisfaction affected purchasing decisions (Oktaviani et al., 2019). The results of this study provide insight to business actors to develop the business by understanding factors influencing purchasing decisions, and to helps in planning and implementing marketing strategies to increase the purchasing decision of the customer at MSME Argotelo.

\section{CONCLUSION}

Based on the results of the analysis and discussion above, it can be concluded that eWOM influences purchasing decisions; customer satisfaction influences purchasing decisions; and eWOM and customer satisfaction influence purchasing decisions. The independent variables of eWOM (X1) and Customer Satisfaction (X2) affect purchasing decisions (Y). The more intensive eWOM and consumer satisfaction on the product, the stronger the purchasing decision.

\section{REFERENCES}

Agarwal, S., Wang, L., \& Yang, Y. (2021). Impact of transboundary air pollution on service quality and consumer satisfaction. Journal of Economic Behavior \& Organization, 192. https://doi.org/10.1016/j.jebo.2021.10.002.

Agustinus, A., \& Junaidi, A. (2020). Pengaruh Sosial Media (Instagram) dalam Meningkatkan Brand Awareness Kopi Kenangan. Prologia, 4(2), 339. https://doi.org/10.24912/pr.v4i2.6605.

Atiko, G., Sudrajat, R. H., \& Nasionalita, K. (2016). Analisis Strategi Promosi Pariwisata Melalui Media Sosial Oleh Kementerian Pariwisata RI (Studi Deskriptif Pada Akun Instagram @Indtravel). Jurnal Sosioteknologi, 15(3), 378-389. https://doi.org/10.5614/sostek.2016.15.3.6.

Bigdellou, S., Aslani, S., \& Modarres, M. (2022). Optimal promotion planning for a product launch in the presence of word-of-mouth. Journal of Retailing and Consumer Services, 64. https://doi.org/10.1016/j.jretconser.2021.102821.

Blake, K. D., Gaysynsky, A., Mayne, R. G., Seidenberg, A. B., Kaufman, A., D’Angelo, H., Roditis, M., \& Vollinger, R. E. (2022). U.S. public opinion toward policy restrictions to limit tobacco product placement and advertising at point-of-sale and on social media. Preventive Medicine, 155. https://doi.org/10.1016/j.ypmed.2021.106930.

Burbules, N. C., Fan, G., \& Repp, P. (2020). Five trends of education and technology in a sustainable future. Geography and Sustainability, 1(2), 93-97. https://doi.org/10.1016/J.GEOSUS.2020.05.001.

Chang, H.-H., \& Su, J.-W. (2022). Sustainable consumption in Taiwan retailing: The impact of product features and price promotion on purchase behaviors toward expiring products. Food Quality and Preference, 96. https://doi.org/10.1016/j.foodqual.2021.104452.

Chawla, Y., \& Chodak, G. (2021). Social media marketing for businesses: Organic promotions of web-links on Facebook. Journal of Business Research, 135. https://doi.org/10.1016/j.jbusres.2021.06.020.

Darmawan, A., Wong, H., \& Thorstenson, A. (2020). Integrated sales and operations planning with multiple products: Jointly optimizing the number and timing of promotions and production decisions. Applied Mathematical Modelling, 80. https://doi.org/10.1016/j.apm.2019.12.001.

Eslami, S. P., Ghasemaghaei, M., \& Hassanein, K. (2021). Understanding consumer engagement in social media: The role of product lifecycle. Decision Support Systems, 3. https://doi.org/10.1016/j.dss.2021.113707.

Fardiah, D., Rinawati, R., Darmawan, F., Abdul, R., \& Lucky, K. (2020). Media Literacy for Dissemination Anticipated Fake News on Social Media. Mediator: Jurnal Komunikasi, 13(2). https://doi.org/10.29313/mediator.v13i2.6624.

Feng, N., Chen, J., Feng, H., \& Li, M. (2021). Promotional pricing strategies for platform vendors: Competition between first- and third-party products. Decision Support Systems, 151. https://doi.org/10.1016/j.dss.2021.113627.

Geng, S., Law, K. M. Y., \& Niu, B. (2019). Investigating self-directed learning and technology readiness in blending learning environment. International Journal of Educational Technology in Higher Education, 16(1), 17. https://doi.org/10.1186/s41239-019-0147-0.

Hanaysha, J. . (2017). Impact of Social Media Marketing, Price Promotion, and Corporate Social Responsibility On Customer Satisfaction. Jindal Journal of Business Research, 6(15), 1-14. https://doi.org/10.1177/2278682117715359.

Handoko, B. (2017). Pengaruh Promosi, Harga Dan Kualitas Pelayanan Terhadap Kepuasan Konsumen Pada Titipan Kilat JNE Medan. Jurnal Ilmiah Manajemen Dan Bisnis, 18(1), 61-72. https://doi.org/10.30596\%2Fjimb.v18i1.1098.

Hanna, B., Kee, K. F., \& Robertson, B. W. (2017). Positive Impacts of Social Media at Work: Job Satisfaction, 
Job Calling, and Facebook Use among Co-Workers. SHS Web of Conferences, 33(SHS Web Conf), 00012. https://doi.org/10.1051/shsconf/20173300012.

Hidayat, R. (2015). Pengaruh Kepuasan Konsumen Terhadap Keputusan Pembelian Lampu Phillip (Studi Kasus Pada Mahasiswa Telkom University). Ecodemica: Jurnal Ekonomi, Management Dan Bisni, 3(1), 305-310. https://doi.org/10.31294/jeco.v3i1.57.

Ievansyah, I., \& Sadono, T. P. (2018). Personal Branding Dalam Komunikasi Selebritis (Studi Kasus Personal Branding Alumni Abang None Jakarta Di Media Sosial “Instagram”). Bricolage : Jurnal Magister Ilmu Komunikasi, 4(02), 149. https://doi.org/10.30813/bricolage.v4i02.1658.

Ilhamudin, M. (2020). Analisis Kepuasan Konsumen Terhadap Produk Unggulan Sektor Makanan Kota Mataram (Studi Kasus Pada Tahu Abian Tubuh). Jurnal Magister Manajemen Universitas Mataram, 9(2). https://doi.org/2548-3919.

Imron. (2019). Analisa Pengaruh Kualitas Produk Terhadap Kepuasan Konsumen Menggunakan Metode Kuantitatif Pada CV. Meubele Berkah Tangerang. Indonesian Journal Software Engineering, 5(1). https://doi.org/10.31294/ijse.v5i1.5861.

Kintu, M. J., Zhu, C., \& Kagambe, E. (2017). Blended learning effectiveness : the relationship between student characteristics , design features and outcomes. International Journal of Educational, 14(7), 1-20. https://doi.org/10.1186/s41239-017-0043-4.

Lang, L. D., Lim, W. M., \& Guzmán, F. (2022). How does promotion mix affect brand equity? Insights from a mixed-methods study of low involvement products. Journal of Business Research, 141. https://doi.org/10.1016/j.jbusres.2021.12.028.

Latief, F., \& Ayustira, N. (2020). Pengaruh Online Customer Review dan Customer Rating Terhadap Keputusan Pembelian Produk Kosmetik di Sociolla. Jurnal Mirai Management, 6(1), 139-154. https://doi.org/10.37531/mirai.v5i3.696.

Li, Z., Yada, K., \& Zennyo, Y. (2021). Duration of price promotion and product profit: An in-depth study based on point-of-sale data. Journal of Retailing and Consumer Services, 58. https://doi.org/10.1016/j.jretconser.2020.102277.

Liao, S., Hong, J.-C., Wen, M.-H., Pan, Y.-C., \& Wu, Y.-. (2018). Applying Technology Acceptance Model (TAM) to explore Users' Behavioral Intention to Adopt a Performance Assessment System for E-book Production. EURASIA Journal of Mathematics, Science and Technology Education, 14(10). https: //doi.org/10.29333/ejmste/93575.

Marta, R. F., \& William, D. M. (2016). Studi Terpaan Media Pemasaran Melalui Posting Instagram Terhadap Ekuitas Merek Pelanggan Sumoboo! (Analisis Eksplanatif pada Komunitas Food Blogger \#WTFoodies). Jurnal Komunikasi, 8(1). https://doi.org/10.24912/jk.v8i1.50.

Mo, Z., Li, Y., \& Fan, P. (2015). Effect of Online Reviews on Consumer Purchase Behavior. Journal of Service Science and Management, 8(3), 419-424. https://doi.org/10.4236/jssm.2015.83043.

Morrison. (2018). Science, Technology, and Society Studies. Encyclopedia of the Anthropocene, 4. https://doi.org/10.1016/B978-0-12-809665-9.10310-6.

Moudi, M., Galoie, M., Yuan, H., Motamedi, A., Huang, P., \& Shafi, M. (2021). Dynamic multi-objective programming model for improving consumer satisfaction within water supply system under uncertain environment. Journal of Environmental Management, 293. https://doi.org/10.1016/j.jenvman.2021.112897.

Oktaviani, N., Astuti, W., \& Firdiansjah, A. (2019). Pengaruh Kepuasan Konsumen Terhadap Pembentukan Komitmen Pelanggan dan e-WOM Pada Pengguna Aplikasi e-Money “OVO.” Jurnal Manajemen Dan Pemasaran Jasa, 12(1), 93-112. https://doi.org/10.25105.jmpj.v12i1.3757.

Ong, D. (2020). Analisa Penggunaan Sistem Sosial Media Terhadap Dampak Pemasaran Penjualan Produk Pada Umkm. Jurnal Ilmiah Teknologi Informasi, 15(2), 26-36. https://doi.org/10.35842/jtir.v15i2.345.

Pardede, R. (2017). Pengaruh Persepsi Harga dan Kualitas Produk Terhadap Keputusan Pembelian Konsumen Yang Dimediasi Kepuasan Konsumen. Journal of Business \& Applied Management, 10(1). https://doi.org/10.30813/jbam.v10i1.870.

Purnomo, N., Arief, M., \& Wantara, P. (2019). Analisis Kualitas Website Dan Reputasi Vendor Terhadap Keputusan Pembelian Online Dengan Kepercayaan Konsumen Sebagai Variabel Intervening ( Studi Pada Pembeli Online Tokopedia Di Kabupaten Lamongan ). Jurnal Studi Management Dan Bisnis, 6(1). https://doi.org/10.21107/jsmb.v6i1.6673.

Rahardja, U., Lutfiani, N., \& Amelia, S. (2019). Creative Content Marketing In Scientific Publication Management In Industrial Era 4.0. Aptisi Transactions on Management (ATM), 3(2), 168-178. https://doi.org/10.33050/atm.v3i2.991.

Sinha, S. K., \& Verma, P. (2020). Impact of sales Promotion's benefits on perceived value: Does product category moderate the results? Journal of Retailing and Consumer Services, 52. 
https://doi.org/10.1016/j.jretconser.2019.101887.

Soliana, \& Pratomo. (2016). Antaseden dari Word Of Mouth. Jurnal Ekonomi, 7(1), 1-8. https://doi.org/10.47007/jeko.v7i01.1515.

Supadiyanto, S. (2020). (Opportunities) Death of Newspaper Industry in Digital Age and Covid-19 Pandemic. Jurnal The Massager, 12(2). https://doi.org/10.26623/themessenger.v12i2.2244.

Tantriana, D., \& Widiartanto. (2019). Pengaruh Aksebilitas , Experiental Marketing dan Electronic Word of Mouth ( eWOM) Terhadap Keputusan Berkunjung Kembali Melalui Customer Satisfaction. Jurnal Ilmu Administrasi Bisnis, 18(3), 1-11.

Xiaoyan, Z., Can, J., \& Tao, Y. (2019). Optimal decisions on product reliability, sales and promotion under nonrenewable warranties. Reliability Engineering \& System Safety, 192. https://doi.org/10.1016/j.ress.2018.09.017. 